\title{
Faith, Liberation, and Revolution in Fire From the Mountain by Omar Cabezas*
}

\section{Fe, liberación y revolución en La montaña es más que una inmensa estepa verde de Omar Cabezas}

\begin{abstract}
Resumen
Publicado en 1982, el testimonio La montaña es más que una inmensa estepa verde (La montaña) de Omar Cabezas sigue generando interés en el campo de la literatura latinoamericana, particularmente entre la crítica que se dedica al testimonio y el posttestimonio. Reconocida como una de las obras fundamentales del testimonio contemporáneo, La montaña describe el despertar político e ideológico de Cabezas antes de la revolución sandinista (1977-1979) en Nicaragua, los orígenes de su relación con el Frente Sandinista de Liberación Nacional y sus esfuerzos en la lucha contra la dictadura de Anastasio Somoza. A lo largo del texto hay frecuentes referencias a la propia fe del narrador, el catolicismo y Dios a la vez que llega a comprender la realidad del pueblo nicaragüense y considera la autoridad moral de la revolución al intentar destituir a Somoza. Nuestra intención es demostrar que, en $L a$ montaña, Cabezas implícitamente considera la influencia de su fe, el catolicismo y Dios en la lucha revolucionaria. Primero contextualizaremos nuestro estudio dentro de las discusiones sobre el testimonio latinoamericano y procederemos a aproximarnos a La montaña desde una perspectiva liberacional que emplea la teología de la liberación como punto de referencia teórico.
\end{abstract}

Palabras claves

Cabezas, Nicaragua, Sandinista, liberación, testimonio.

* I would like to thank my colleague David Inczauskis for his insightful comments. 


\begin{abstract}
Published in 1982, the testimonio Fire from the Mountain (La montaña es más que una inmensa estepa verde) by Omar Cabezas continues to generate interest in the field of Latin American literature, particularly amongst critics dedicated to the testimonio and post-testimonio. Considered one of the fundamental works of contemporary testimonio, Fire from the Mountain narrates the political and ideological coming of age of Cabezas during the years preceding the Sandinista revolution (1977-1979) in Nicaragua, the origins of his relationship with the Frente Sandinista de Liberación Nacional (FSLN), and his efforts in the struggle against the dictatorship of Anastasio Somoza. Throughout the text there are frequent references to his own faith, Catholicism, and God as he comes to terms with the plight of the Nicaragua people and considers the moral imperative of the revolution to depose Somoza. Our intention is to demonstrate that, in Fire from the Mountain, Cabezas implicitly considers the influence of his faith, Catholicism, and God on the revolutionary struggle. We will first contextualize our study within discussions on the Latin American testimonio and proceed to frame our study of Fire from the Mountain within a liberational perspective that references liberation theology as our theoretical touchstone.
\end{abstract}

Keywords Cabezas, Nicaragua, Sandinista, liberation, testimonio.

In 2018, public demonstrations in Nicaragua against the planned reforms of the social security system by the administration of Daniel Ortega once again placed the nation in the international spotlight. Beginning in León on the $18^{\text {th }}$ of April and spreading throughout the country on the $19^{\text {th }}, 20^{\text {th }}$, and $21^{\text {st }}$ of that month, university students and others clashed with riot police and supporters of the government such as members of the Juventud Sandinista in an attempt to request that Ortega repeal the stated social security reforms. Although on April $22^{\text {nd }}$ Ortega announced that he was revoking the reforms, many Nicaraguans continued to demonstrate in public and express their disapproval of the president and vice-president, his wife Rosario Murillo. The Catholic bishops in Nicaragua, for example, came out firmly in support of the students, convened a number of pacific demonstrations, and visited parishes and dioceses that had been affected by the violence. Speaking in an interview in May 2019, the comandante Omar Cabezas seemed rather oblivious to the roots of the public protests and declared his allegiance to Ortega, Murillo, and the Sandinista revolution, blaming the influence of other countries on the domestic instability and asserting that "cuando la historia se escriba, en unos 30 o 40 años más verán las maravillas del sandinismo, de cómo sobrevivimos a los trucos de los 
gringos y europeos" (Cabezas Interview). As the author of La montaña es algo más que una inmensa estepa verde (1982) (Fire From the Mountain) and Canción de amor para los hombres (1988) (Song of Love for Mankind), two volumes of testimonio that, respectively, recount his initiation into the movement and his participation in the armed revolution against the régime of Anastasio Somoza Debayle, Cabezas is only too well aware of the troubling paradoxes of history. The abundant descriptions in Fire From the Mountain, for example, of his emerging revolutionary ideals are complemented by the presence of language, colloquial expressions, and popular images that evoke a Catholic upbringing. Our intention is to demonstrate that, in Fire From the Mountain, the presence of the narrator's own Catholicism and his commitment to justice and the revolution come together and dovetail with discrete elements of liberation theology.

Since the first Casa de las Américas literary prize for testimonial narrative was awarded in 1970, testimonio has been subject to a variety of definitions that have often contributed more to muddying the theoretical waters than to mapping its shoreline. While some trace the origins of the testimonio to the first European chronicles and reports written at the beginning of the Conquest (Prada Oropeza 7) and to the works of Simón Bolívar and José Martí (Beverley “The Margin” 25), the first contemporary manifestations of the genre may be found in works such as Biografía de un cimarrón (1966) by Miguel Barnet and Operación masacre (1970) by Rodolfo Walsh, as well as the essays, fiction, and poetry published in the Chilean journal Solidaridad (1976-1990). According to Arturo Arias, "From a Latin American perspective, testimonio began as a means of creating primary sources for research to gain knowledge of Latin America's own social formation in the 1970's. This process gradually evolved into an attempt to understand the social causality and subjective logic behind the breadown of civil society after the experience of political violence and increased authoritarianism" (Taking Their Word 133-34). The fact that it has largely been the academies in North America and Europe that have forged the descriptions of testimonio belies the reality that the genre incorporates distinct literary categories of representation simultaneously and that it 
is habitually produced as an oral document by cultures located principally in emerging economies. Many of the canonical definitions of testimonio, for example, seem to suggest that the text exhibits an osmosis, capable of absorbing the most significant characteristics of a representative life and, through the intervention of a transcriber that aids in (re)telling the story, transforming it into something familiar to those audiences unfamiliar with the political or historical context. As we continue to examine the ability of testimonio to reconstruct the relationship between literature and the public and to survey the varied relationship between popular culture and canonical aesthetics, the substantial characterizations of the genre expressed by critics such as John Beverley and George Gugelberger have today been surpassed by multiple discursive considerations. The post-Stoll reckoning of the testimonio has allowed the genre to be more effective in its efforts to encourage change through an attentiveness to the relationship between social issues and literary aesthetics. As Cabezas declared in 1983, "El testimonio tiene que estar sirviendo para allanar el camino, para hacer más fácil el camino, para ayudarles a otros a caminar. [...] Yo pienso que el testimonio, como género, debe servir para construir hombres, que con su experiencia ayuden a otros" ("El testimonio" 125).

In Nicaragua, the testimonio has enjoyed a rich and varied history that, in the opinion of Verónica Rueda Estrada, began with the publication in 1930 of Maldito pais by José Román (147), a work that transcribes a number of conversations that the author had with an Augusto Sandino "que siempre tuvo presente en su ideario que era el servidor de una causa y de una fuerza superior" (Midence 9). This revolutionary spirit continued to inspire national events and contributed to the foundation of the Frente Sandinista de Liberación Nacional in 1961 and the victory in 1979 of the Sandinista Revolution (also known as the Guerra Popular Sandinista) against the government of Anastasio Somoza. The establishment in 1979 of the Ministry of Culture and of the Instituto de Estudios del Sandinismo, in which "los testimonios de ex guerrilleros, militantes, colaboradores y bases de apoyo serían determinantes para la elaboración de 'la nueva historia de Nicaragua"' (Rueda Estrada 150), would lead to multiple thematic 
categories of testimonial expression. As Rueda Estrada has indicated, "el testimonio ha servido al desarrollo de las letras nicaragüenses, al intercambio de ideas políticas y a la construcción de la memoria sobre el pasado, gracias a las obras de simpatizantes somocistas, ex sandinistas, ex contras e incluso de extranjeros que participaron o en la Contra o a favor del gobierno sandinista” (157).

Born in 1950 in León, Nicaragua, Cabezas became active in the Frente after participating in campus politics at the Universidad Nacional Autónoma de Nicaragua (UNAN) in his hometown and joining the Frente Estudiantil Revolucionario (FER), a branch of the FSLN. His celebrated work Fire From the Mountain describes his experiences with the FER at the UNAN, his incorporation into the FSLN and, subsequently, his activity in the mountains of northern Nicaragua before and during the revolution. While critics have largely ignored his second book, Canción de amor para los hombres, and continue to examine any number of discrete elements present in Fire From the Mountain, the themes of faith, religion and theology in his work have remained mostly untouched. One valuable exception is the study of the interstices between Fire From the Mountain and the Popol Wuj that Thomas Ward has offered in his work Decolonizing Indigeneity (59$60)$.

In Latin America, the eurocentric Christian theology that was forced upon the continent over five centuries ago continues to be transformed by historical events, political developments, and demographic changes. Elaborated in Europe after years of theological controversy, many Latin American cultures constructed their own synchretic Catholicism through such figures as the Mexican Virgin of Guadalupe and the Peruvian Santa Rosa of Lima, among many others, and the influences of indigenous, Asian and other non-Christian cultures. The same occurred with the transformation of traditional Christian theological discourse. From a Eurocentric perspective, "making theology" meant beginning at the theoretical levels of thinking, invoking Church authorities, and studying their writings, only then applying them to daily life. In Latin America, social and political circumstances produced other voices and other theologies that would 
synthesize Catholic ideals and Latin American realities. Liberation theology and liberation philosphy, for example, represented critical reactions to the indiscriminate application of European theology and philosophy. As Dina V. Picotti has written, what would come to be known as liberation philosophy "emphasized the need for freedom from normative Eurocentric logic, which conditioned and impaired the continent's sense of identity and its concrete display in all layers of society" (188). Since the elaboration of an emancipatory discourse, churches of multiple denominations throughout Latin America began to address economic inequalities at the local, regional, and national levels from a number of theological positions that consider ecumenical praxis, material reality, and the distinctiveness of their respective communities. The attention that liberation discourse has given to material deprivation and to the denunciation of economic injustice, however, may participate in depersonalizing the exploited subjects by idealizing and romanticizing the circumstances of their impoverished existence (Gutiérrez 22-23, Segundo "Crítica y autocríticas" 234) and expressing a "messianism of the poor" (Puleo 199). From the moment of its theological birth and for years to come, liberation philosophy faced challenges both within and from outside the Catholic Church: On one front, the voices of liberation were silenced by integrating the principle ideas of liberation theology into more contemporary canonical Church teachings; on another, the fall of the Berlin Wall in 1989 and the assumed demise of Marxist ideologies weakened the social hermeneutics that were favored by liberation philosophers and theologians. As Lilian Calles Barger writes, "For many observers, liberation theology has failed as a political or religious movement. Liberation theologians founded no institution, proposed no singular program for change, and established no school - the key features of a recognized movement. Its social expression in disparate communities has been too diverse to coalesce into mass action" (9). "In the new millenium," however, "liberation theology returned with a roar, alarming its critics and mystifying most of the public" (Calles Barger $3)$. 
The victory of the Sandinista Revolution in 1979 represented a unique opportunity in Nicaraguan history to incorporate the more progressive social ideas espoused by liberation thinkers and theologians to the political program advocated by the National Directorate of the FSLN. Clergy such as Miguel D'Escoto and the brothers Ernesto and Fernando Cardenal, among others, played prominent roles in the Sandinista government (1979-1990) and made important contributions to laws and policies that combined a liberation perspective with the political goals of the National Directorate. While priests such as the Cardenal brothers actively participated in the post-war reconstruction of Nicaragua and enjoyed a relatively productive and respectful relationship with members of the Sandinista executive committee, the Church hierarchy in Rome staunchly objected to their political responsibilities and to their very public participation in the national government. The growing tension between the Catholic Church hierarchy in Nicaragua and those priests who were steeped in liberation philosophy and were part of the growing "popular church" came to a head March 5, 1983, when Pope John Paul II visited the country and, upon his descent to the tarmac at the Managua airport, publicly admonished Ernesto Cardenal for his participation in political affairs. Over thirtyfive years later, events in Nicaragua in 2018 again forced the hand of the Catholic Church, as priests and bishops declared that they were standing with the people and that they supported a dialogue between the administration of Daniel Ortega and representatives of the demonstrators. On July 9, 2018, the Nicarguan Cardinal Leopoldo Brenes led a group of Nicaraguan bishops to Diriamba to negotiate the release of a group of nurses and Franciscan missionaries that had taken refuge in the Basilica of San Sebastián and to show support for the victims of attacks by soldiers and paramilitary groups there that left 14 people dead. As they arrived at the church that day, a group of people began to attack them and protest their presence, calling them "liars" and "murderers" due to the growing participation of the Catholic Church in Nicaragua in national affairs and criticizing them for their association with organizations such as the Asociación Nicaragüense Pro Derechos Humanos (ANPDH) and the Coalición Universitaria. In an official statement, the 
Conferencia Episcopal de Nicaragua stated that the delegation "cumplía la misión de Jesucristo, estar al lado del pueblo sufriente, una visita pastoral a Sacerdotes y fieles de la zona de Carazo, víctima de policías, paramilitares y turbas produciendo muerte y dolor" (Conferencia Episcopal). Injured in the encounter, Bishop Silvio José Baez posted to Twitter "What matters least is what they did to us today, the blows \& the wound that I suffered. What our people suffer is much more serious; today more than ever the Church will be at the side of the people, those who have no voice, those who don't have the strength to ask for help" (Baez).

In Fire From the Mountain, the role of religion and personal faith in the enunciation of a liberational or revolutionary narrative has been largely unexamined and the position of Cabezas as unwitting theologian has gone undetected. Instead, the majority of critics and reviewers of the work have examined the construction of a revolutionary discourse (Barbas Rhoden, Hernández Novas, Jones, Mantero, Ross, Tirado), the boundaries of testimonio (Hood, McAlllister, Ward, La resistencia cultural), the latent or changing machismo in the text (Orr), or its ecological implications (Quin). Critics have also examined the language employed by Cabezas, particularly the role of orality and the tension between the spoken and written word. Claire Pailler, for example, indicates that oral devices throughout the work "allowed flexibility in writing" (210); Raúl Hernández Novas affirms that "The narration quickly wins us over because of its rigor, freshness, and sponteneity, due precisely to its conversational character and to Cabezas being an extraordinary storyteller" (131); Seymour Menton indicates that "The colloquial conversational style, sprinkled with an occasional poetic image, is most effective in providing the reader with an overall view of the revolutionary movement within" (437); and Stephen Legeay insists that it employs "a 'language of liberation"” that transcends the writer's individual circumstances (353). As David Bray summarizes, "What he told the tape recorder emerges between book covers as an engaging, sensitive, and romantic memoir, complete with the sound effects of spoken language" (48). The importance of progressive Catholic/Christian ideals for the Sandinista Revolution, however, cannot be 
overestimated, particularly when considering the impact that the revolutionary mysticism of Augusto Sandino would have on the ideology of the Frente. In letters and communiqués, for example, Sandino employed a quasi-religious language and consistently referenced Catholic figures and expressions, fusing these with a revolutionary mysticism that looked, above all, to rid Nicaragua of the presence of the United States and of any compatriots that supported it. In the "Circular a las autoridades de las Segovias" dated May 19, 1927, Sandino wrote "No me importa que se me venga el mundo encima, pero cumpliremos con un deber sagrado" (106); in a manifesto from July 1, 1927, Sandino declares "No seré Magdalena que de rodillas implore el perdón de mis enemigos, porque creo que nadie tienen el derecho en la tierra de ser el semidiós humano" (119); and in a letter to the Honduran writer Froylán Turcios dated September 27, 1927, Sandino affirms, "Una vez mas puede Ud. estar convencido, que el grande amor a mi patria y el deseo de verla libre, así como la fe en Dios, sabrán alentar a mi ejército y a mí para seguir luchando contra los invasores de mi patria, hasta castigarlos sangrientamente y arrojarlos fuera de nuestro territorio" (153-154). In these examples, the references to a "deber sagrado," to his faith in God and to Mary Magdalene speak to an authority that transcends earthly matters and manages to connect the struggle against the United States to a larger responsibility that articulates a concern for the less fortunate of Nicaragua yet predates the formulation of the principles of liberation theology by some forty years. Even his language contains hints of the Old Testament and of a national crusade inspired by faith, as he proclaims that he will "seguir luchando" and that he will punish "sangrientamente" those "invasores de mi patria" and "arrojarlos fuera de nuestro territorio."

While the biblical language and vivid images of the struggle may aid in portraying the enemy, the construction of a political platform requires the amalgamation of passionate designs and concrete measures. In this respect, religious or spiritual faith may empower this process. Writing a few years before his death in 1989, Ignacio Ellacuría declared: 
Indeed, initially faith does stimulate the concerned to political commitment; secondly it stimulates to revolutionary political commitment wherever structural injustice is the defining characteristic of the situation; finally it stimulates to effective actions and, therefore, support of those undertakings that can combat injustice and institute a new social order. It is faith that keeps one from belonging to parties that justify the status quo, in one form or other, and it is faith that gives one the stimulus to put oneself at the service of the parties that combat the status quo and that try to substitute for it whatever will support the causes and rights of the people. (28-29)

There is a tone present throughout Fire From the Mountain that underscores the significance of faith: In the revolution, in his fellow guerrilleros, in the Nicaraguan people. Raised Catholic, Cabezas' faith transcends the merely religious; yet the religious language and imagery represent a surprising touchstone for the revolutionary discourse as he constructs his narrative within the broader context of the Sandinista revolution. In the process, he renews his own faith in his fellow human beings and in the institutions we create and implicitly brings together distinct yet not incompatible systems of belief. For example, Fire From the Mountain begins with a description of Holy Week in León:

During Holy Week my hometown is a ghost town, with medieval trimmings. Holy Week in León is hot, blistering hot: the pavement is hot, the dust is hot, the car seats are hot, the park benches are hot, even the water out of the tap is hot. . . . In the center of town there aren't even people - they all go to the sea. I'm talking about the middle class, who live where the streets are paved, where the rich people live, in the center of the town. (1) 
In this first paragraph, Cabezas vividly describes the oppressive heat that affects the city during this time of year, signifies the importance of Holy Week for the residents and, at the same time, establishes the significance of class differences. As the leonesa writer Gina Sacasa-Ross has described, "La Semana Santa en mi León de Nicaragua, ciudad provinciana de sencillas costumbres moldeada por la religión católica, era una mezcla de desbordante alegría y fervor religioso." The explicit superficial details offered in the text are evident: the heat is stifling, and everyone who lives in the city leaves and goes on holiday to the beach. The implicit commentary, however, is more striking: those who do not have the means-who do not live "where the streets are paved"-cannot escape the heat, they cannot travel, even during Holy Week, one of the most sacred times during the Christian liturgical year. The reference to this holiday is not accidental, as it frames his description of León and constructs an unspoken relationship between religious expression, class distinctions, Catholicism and his own political awakening. While this first paragraph of Fire From the Mountain may not carry the weight of an ecumenical pronouncement, it does confer a privileged position to this religious celebration and to the the cues and prompts which Cabezas utilizes in reconstructing his memories and the trajectory of his participation in the revolution. At this time in Nicaragua in the mid- to late 1960 's, it is no coincidence that "a vital nucleus of Catholics and Protestants found that their religious faith offered strong motives to join the cause of popular insurrection" (Dodson and O'Shaughnessy 3). Growing up in León during the sixties, it seems plausible that Cabezas shared in the zeal during Holy Week in León and assimilated the renewal of the Catholic Church, relating these to the incipient revolutionary struggle against Somoza. The significance of Holy Week is not lost on the reader, as the suffering, death, and rebirth of Jesus find their potential symbolic parallel in the rebirth of Cabezas when he becomes a member of the Frente that same week.

Over the course of the first chapter there are also a number of references that allow the reader to connect Holy Week to the growing class consciousness of the narrator. Recalling his entry into the Frente, Cabezas notes that "I remember it 
was during Holy Week that I joined the Frente Sandinista, right after I graduated from high school" (5), implicitly conflating Holy Week, the Frente, and his participation and future role in the movement to depose Somoza. This association, however, reveals a deeper potential bond that represents the beginning of an operating theology inclusive of both the traditional elements of Catholicism (the celebration of mass, the eucharist, solemnity) and of the revolution (class consciousness, political and military activism). In this first chapter, the author also indicates that "a code name for the Frente" was the "Church" (10), bringing together the Nicaraguan revolutionary effort and a sense of spiritual purpose that typically characterizes a church community. Over the course of these initial pages the reader comes across the first of many exclamations that originate in Christianity and, specifically, in Catholic spirituality. When his friend Juan José Quezada asks him if he wants to join the Frente, Cabezas indicates that his first reaction was to exclaim "Blood of Christ!” (9). This expression in Spanish, “'Sangre de Cristo!”, draws attention to an unexpected element of the moment, not unlike the use of "Holy" in English expressions such as "Holy cow" or "Holy smokes" to convey surprise or astonishment.

A few pages in, Cabezas describes Lezama's pool hall, one of the few places open in León that time of year. There, "During Holy Week at least 150 people were jam-packed into the hall, and so many bodies just in off the hot street made it very close and stuffy inside" (4). Although the solemnity of Holy Week requires that most social and communal activities be sharply curtailed in order to respect the gravity of those days, the authorities allowed a select number of locales such as Lezama's to remain open. Brothels and prostitutes, states Cabezas, would restrict their activities: "The whores in León have always been superreligious; they were all pretty much God-fearing women. They didn't fuck on Holy Days, let me tell you. Good luck finding a whore on Good Friday in Leon! They started fucking again on Holy Saturday" (5). While the observations he offers represent a noticeably patriarchal attitude that links religious expression with male pleasure and prostitution, it is curious that every fragment includes a devout expression: 
"superreligious," “God-fearing," "Holy Days," "Good Friday,” and "Holy Saturday" blend easily with his carefree attitude regarding the difficulties of finding a prostitute during Holy Week. This mindset, however, must also be considered alongside the significance of Cabezas's consideration of this marginalized and stigmatized population and the manner in which their profession exists alongside their own faith. In fact, critics such as Martha Nussbaum and Sybil Schwarzenbach "have questioned the feminist critique of prostitution and called for a more robust defense of a right to its practice" (Gauthier 166), arguing that "all or nearly all of the objectionable aspects of the current practice are ultimately the consequence of an unreasonable moral and legal stigma against prostitutes and their trade" (Gauthier 166). By subverting traditional values and allowing a type of cultural resistance to creep into the narrative, prostitution in the context of Fire From the Mountain may also represent a revolutionary action that participates in the dismantling of the traditional Catholic culture so frequently invoked by the Somoza government. While Cabezas may not necessarily be utilizing the absence of prostitutes on Good Friday in León to assemble his own theology, it does appear that his awareness of those socially and economically marginalized and his rather glib use of colloquial expressions grounded in Catholic tradition are gradually fusing themselves with his political activism and with the Frente. It is no coincidence that, in this same chapter, Cabezas draws attention to how "the rich" stay in their homes or leave León during Holy Week "just to make sure they wouldn't get caught up in that swarming mass of poor people in the processions" (3).

After the first chapter and throughout the work, there are numerous passing references and expressions that illustrate the connection between religion, faith, and revolutionary identity and originate in Christian faith and theology. When he makes the decision to leave León and travel to the mountains in the north, for example, he references an event in the death of Jesus Christ to locate this watershed moment in his life: "And there my Calvary began, the moment I left that house. A new phase began in my physical life, in my beliefs, in the development of my personality, in 
everything, in maturity, in everything, everything" (53). When he arrives at his first camp and sees that there are only some 15 to 20 revolutionaries, he comes face-toface with the challenges that they will face and considers abandoning the struggle: "You are right at the point of saying to yourself, Holy Mother of Christ!" (17). Throughout the work there are also a number of specific mentions of God. When he departs for the mountains and is suffering the steep hills for the first time, for example, Cabezas notes: "I hoped to God the mud would be level on ahead, but the fact was the trail wound up and down through the mountains, with now and then a deep ravine alongside" (61). As he languishes in the camp a few months later, complaining of pain in his abdomen and contemplating a possible return to León for an appendicitis operation and the possibility of encountering a woman, his thoughts bring together God, intimacy, and uncertainty: "I hoped to God there would be a compañera, but who knows?" (142). As he describes the moment when he is getting prepared to go the hospital in León for the appendectomy, he recalls: "I said to myself, Good God in heaven, what a disaster if they discover me, and the Guard comes and drags me bareass out of bed and starts beating me with their rifle butts" (154). While these examples mention God as part of a plea, all are also distinctly different: his need for relief, the absence of female companionship in the camp, the fear that the Guard may discover his presence at the hospital, that he may suffer physical abuse, and that, as part and parcel of a larger "disaster," the revolutionary programme in the mountains may be jeopardized. At the root of these examples is the passing inclusion of God, whether it be to express physical suffering, to anticipate a possible romantic encounter or to articulate a desire to avoid the worst-case scenario. These colloquialisms, however, do not necessarily represent the existence of an operating theology and may, in fact, evidence how Cabezas subtly co-opts religion and theology for a political project that understandably draws from the well of popular culture. This is a far cry from the ideals of Sandino who, in a letter to Froylán Turcios on Sept. 20, 1927, exclaimed that "solo Dios omnipotente y los patriotas de corazón, sabrán juzgar mi obra" (152). For Cabezas, however, the imprecations that include the Virgin Mary, 
Calvary, hope, and God are subtly intertwined with the ideals of the Frente and with the actions of the guerrilleros in constructing a new nation. In the process, the standards of patience and solidarity implicitly invoked by the religious figures, moments, and events become a tacit part of a theology embedded noiselessly in the broader revolutionary project. The liberation of Nicaragua is thereby directed, in part, by an existential worldview that includes traditional Catholic imagery and suffuses it with a revolutionary potential on a larger scale.

In the narrative, Cabezas suggests God was on the side of the Frente and, by extension, of the Nicarguan people. Describing the beginnings of the Frente Estudiantil Revolucionario (FER) in 1962 on the university campus in León, he writes that "It was a sum total of four or five compañeros that thanks to God and the Virgin had speaking ability and could address assemblies" (20). When in 1971 the Cerro Negro volcano erupted in León and ash blew through the city, Cabezas recalls how he and other students ran through the central market and exclaimed that God was angry with Nicaragua, that the eruption was the fault of Somoza: "As we made our way among the baskets of crabs and clams and green vegetables, we'd moan: 'It's terrible, terrible, it's the wrath of God, the wrath of God, God is punishing us for not kicking Somoza out! And He'll keep right on punishing us because Somoza is still in power!'. We walked by the meatsellers and soft-drink vendors: 'Wrath of God, wrath of God!'. And past booths of clothing: 'Wrath of God!" (144). Those "four or five compañeros" on the university campus that "thanks to God and the Virgin had speaking ability" and the dissemination of the idea that the existence of the Somoza regime contributed to the volcano eruption accentuate the fact that, to the student activists, God is unironically on the side of the Frente and of the people in Nicaragua. It was "He" who instilled in those "four or five compañeros" the talent to use their speech to move others and act against Somoza, and it was "He" that is unreservedly seeking the ouster of Somoza and that has, by extension, joined forces with the Nicaraguan people. The "Wrath of God" broadcast surreptitiously by the students plants the seeds of doubt among those at the market and contributes toward the ultimate ouster of Somoza by 
presenting a clear choice: You are either with God or with Somoza, but you cannot be with both.

The commitment to the ideals of the Frente and the significance of Catholicism for his family and for his native León are brought together by faith: An ethical faith in the revolutionary process and a spiritual faith embodied by the traditions and symbols of the Catholic Church. Published in 1900 by the Uruguayan José Enrique Rodó, Ariel addressed the tumultuous times during the turn of the twentieth century and offered advice for Latin American youth, declaring "That which humanity needs, to be saved from all pessimistic negation, is not so much a belief that all is well at present, as the faith that it is possible through life's growth to arrive at a better state, hastened and discovered by the actions of men" (22). The faith that Rodó underscores is not necessarily grounded in religious ideals but rather in a spiritual ethic that transcends the moment and heralds "a better state" brought about by individual and communal efforts. Decades later, the concluding documents of the Second Vatican Council (1962-1965) and the Second Episcopal Conference in Medellín, Colombia in 1968 would inspire a generation to exercise the well-known "preferential option for the poor." In Nicaragua, during the 1960's and 1970's, "the clergy, the religious, and lay leaders began to act as the organic intellectuals of the poor" (Sawchuck 45) and organized "biblical reflection and pastoral meetings:" "Members came to understand the complex reality of poverty and oppression, came to discover the structural factors underlying these conditions, and came to acknowledge the need to work against these factors as a principle of faith" (Sawchuck 45). As a consequence of liberation thinking, faith, then, came into direct contact with the historical context and resisted these "conditions" and "factors" through individual acts or collective actions that reflected a larger movement or set of principles put into motion. In Fire From the Mountain, there are examples of how the larger revolutionary project impacts Cabezas's faith. Although in the second chapter he declares that "The people and the Frente were thinking along the same lines" (15), there were moments when he doubted the size and efficacy of the movement: 
But sometimes you came crashing down, when smack in the middle of your daily work, your political action, it hit you that really you were dreaming, really you were only a mini-group. Then right away another feeling came over you, like a reserve force or a faith or something like that: you had the feeling that behind the compartmentalization there existed a whole sea of things, people, plans, and resources that you didn't even know about. (15)

As he is acknowledging those conflicting moods, he also realizes that the broader impression was much more abstract, more optimistic: A "faith" that there were multiple sides that could help support the struggle and that he potentially ignored. While this trust in something larger than himself originates in self-doubt, it finds its ultimate significance in untapped resources that he may have no direct knowledge of, "a whole sea of things . . . that you didn't even know about."

Later in the work, Cabezas describes his emotions upon witnessing the popular demonstrations against Somoza in Subtiava and leaving to join the Frente: "So I left for the mountains with boundless faith. And it wasn't just the romantic glow of that march I was telling you about, but this: behind that march was a whole political experience, an organizational experience, an experience of struggle, in this case in the streets. The masses were being mobilized" (47). His commitment to the agenda of the Frente is mediated and conditioned by the events he witnesses and the authority vested in him by the people of Nicaragua. In this sense, his personal faith in the revolution is informed by a blind trust of the people and by the virtue of their struggle. Predictably, this faith is often shaken by setbacks. When an informant reveals the location of his friend and mentor René Tejada-“"Tello"— to the National Guard and is subsequently killed in an ambush, Cabezas is devastated: "I thought sometimes, everything he taught me is useless, because if he didn't apply it, if he didn't use it, it was all pure theory and not worth shit. Nothing was sure anymore. What kind of guerrilla force is it anyhow when the best man of all, your 
teacher, is the first to die?" (118). Reflecting a few pages later on what sustains him and what will safeguard the revolution, he comes to the following conclusion: "You are saved by the fact that the FSLN inculcated in us a historical will, an infinite, boundless stubbornness. And all at once your brain starts to function. Okay, thousands of people may die, but you have to keep on fighting to bring down the enemy" (121). This cycle of doubt and self-renewal is possible through an unlimited confidence in the revolutionary project, in his fellow sandinistas, and in the people, a confidence that emerges from a faith in his own path and in the responsibilities he has assumed. The strength that he gathers from the demonstrations at Subtiava inspire him while he mourns the death of Tello and through the subsequent doubts about his own training and preparation for the revolution, concluding that, in the end, his individual role is inseparable from history. When "Nothing was sure anymore," "stubbornness" carried him through. Noting the positions taken by theologians in developing countries in the 1970's and 1980's, Virgilio P. Elizondo draws attention to their determination: "The theologians of the Third World have had no choice. Because of the poverty of their situation, they have been providentially forced to remain in close contact and solidarity with the questions and struggles of their people" (21). Cabezas's personal faith is supported by a willingness to immerse himself in his historical context and an unwillingness to compromise his ethics.

As expressed in Fire From the Mountain, any faith in his own initiative or in the individual efforts of compañeros is minuscule when compared with his faith in the social and collective capacity of the people to adhere to the revolution and, in the process, to transform their nation. In the second chapter, entitled "Strength and Numbers" in the English translation, Cabezas explains that, when he joined the Frente, he would attend Mass simply to connect with the community and listen to what was being discussed: "I went to Mass in the cathedral of Leon just to hear what people would be saying in the church lobby after the service-the same sort of thing you'd hear in the stadium before a game" (14). Recalling a particularly difficult moment during the Christmas holiday when he and his companions were 
in the mountains, cold and hungry, he realizes that, in the end, those challenges were not new: "We were fairly used to the problems. Because sometimes we spent Christmas in the cathedral [in León] on strike for the political prisoners. What I'm saying is, in a way we were already used to it, from the time we'd been students, used to spending Holy Week or Christmas or New Year's shut up in churches for political campaigns" (110). At first glance, the solidarity that he witnessed during "Holy Week or Christmas or New Year's" in León has little to do with eavesdropping on conversations during Mass. It is clear, however, that both examples reflect an acute political consciousness that links religious expression with intentional action that deliberately takes the side of the marginalized: His membership in the Frente and his participation in political campaigns are grounded in a faith that transcends the moment and works toward the construction of a better Nicaragua.

Later in the work, Cabezas recalls how he and a group of compañeros left the mountains after a particularly tense battle with the National Guard on "La Señorita" and "El Copetudo," two small peaks near Ocotal. Arriving in Estelí, they find refuge in the Calvary Church there and stay with the young parish priest, Father Julio López. Upon entering his bedroom and reflecting on his surroundings, Cabezas recalls the recent battles and waxes poetic:

I don't know why, but on entering the church and the padre's room, the little church of Calvario in Estelí, the roar of what we had lived through on 'El Copetudo' and 'La Señorita' was suddenly hushed. Or was it only the peace of underground protection that I felt, concentrated there in the padre's room? It was as if you didn't want to speak out loud; you didn't want to violate that silence, the silence of the centuries, of everything that had happened before you; you didn't want to disturb the emptiness with the absurdity of your stubborn solitude, your conscious, necessary solitude. And all this stirs you, quite apart from whether or not you believe in God; it's something so personal, so intimate, like the padre's slippers at 
the edge of the carpet, furry slippers that said nothing but only figured as mute witnesses to the weight of a man who lived in that world. (180)

The stark contrast between what he and his men had just lived through and the tranquility of the church and of the priest's living quarters inspires him to consider the presence of silence, of the Nothing that embraces all. At that moment, the sounds and violence of the recent battles dissolve in the face of something larger: a respect for history and for "everything that had happened before you." And in light of the weight of this history, individual concerns are reduced to momentary and self-absorbed concerns. Even the "furry" bedroom slippers owned and used by Father Julio are infused with an aura that, regardless of "whether you believe in God," places his job and responsibilities within the larger historical context. Considered alongside the revolutionary ethic personified by Cabezas, these contemplations draw attention to the link between exterior actions and motivations and an inner, more profound spiritual life. If previous examples throughout Fire From the Mountain tempt us to observe that Cabezas may simply be co-opting the principal tenets of liberation theology for his political project, then the description he offers "on entering the church and the padre's room" accomplishes quite the opposite: His political project — his raison d'etre-, has also been co-opted in order to enunciate a theology that finds immanence in both military battles and the emptiness of the church in Estelí that bespeaks "the silence of the centuries." Herein lies the substance of Cabezas's theology: the noiseless presence of God, in active solidarity with the marginalized and with those struggling for a better life on earth. In essence, his musings exemplify the theology and philosophy of liberation that took hold of some sectors of the Catholic Church during the 1970's and the intimate relationship between history and faith. According to the historian and theologian Evangelista Vilanova, “[la fe] nunca dejará de ser reinterpretada en función de las nuevas cuestiones de los hombres, cuestiones que no son fortuitas, sino que son un aspecto de la revelación de Dios en la historia" (499). As history serves to frame our actions and to condition our responsibilities, unimportant objects come to 
represent something larger and rise above their practical applications. Father Julio's slippers, "mute witnesses to the weight of a man who lived in that world," dignify the challenges he faced as both a priest and as a sympathizer of the Sandinistas and locate his life and work within Nicaraguan history.

The theological and spiritual liberation yearned for by part of the Catholic Church at this time finds its parallels in the political liberation sought by the Frente and, by extension, Omar Cabezas, especially as both of these liberations relate to the marginalized and the oppressed. In Fire From the Mountain, when two elderly peasants, Gilberto and his wife, decide to help Cabezas and offer him food and shelter in a shack near their house, Cabezas decides to attempt to connect with the elderly woman and convince her to continue helping them: "So at night I slipped up to the house, and we started talking about all sorts of things, generalities. 'That's a nice statue of the Virgin you have.' 'Yes,' she said, and since she had another Virgin, the Virgin of Fatima I think it was, I asked, 'The Virgin with the most miracles is the Virgin of Fatima, isn't it, because she never fails you, isn't that right?" (193). Ever the savvy revolutionary, Cabezas decides to tailor his argument to the circumstances of the moment and incorporates a comment that reveals his own personal background and Catholicism. In this case, his faith is in service to the larger revolutionary goal of being able to count on collaborators that will, when needed, offer refuge for fellow Sandinistas. As presented by Cabezas, liberation is mutually beneficial: Neither the Virgin of Fátima nor the revolution will fail the elderly couple.

Toward the end of Fire From the Mountain, Cabezas once again recalls the challenges he faced upon leaving for the mountains and describes the process of actively becoming a revolutionary. Initially, this process required "the forced shedding of your present" (201), painfully abandoning your pre-Frente life and constructing your new Sandinista identity. As you continue, Cabezas notes, you reach the point where, although you have discarded your past self, you have not yet reached your spiritual destination: "Finally the moment comes when nothing is left of your past, in terms of your experience, your senses-I'm not sure how to say 
it-your immediate, recent past, it no longer exists" (202). In the narrative moment, he describes the act of eating an orange: "I started peeling an orange with my pocket knife, and as I separated the rind from the pulp of the orange, as I saw the bits of peeling falling away, separating, giving way to the knife, I felt I was like that orange, and the orange peelings were the things I ought not to think about" (207). This process of purging himself of his past life and trappings and of searching for meaning within that subsequent emptiness is not unlike the search for a total and complete union with God exemplified by mysticism and by the life and works of St. John of the Cross and St. Teresa of Ávila. In this respect, the liberation of the people must, by necessity, be a direct consequence of Cabezas's liberation from his own past. His newly-found revolutionary mysticism uses as his touchstone a rebirth, freed from mundane and selfish concerns. Only upon emancipating himself from his past can he prepare himself to fight for others and to promote the goals of the revolution ahead of his own. In essence, his faith in the revolution has allowed his own struggle for justice and the struggle of fellow Nicaraguans to free themselves from Somoza to become one and the same.

Fire From the Mountain by Omar Cabezas documents his militancy in the Frente and his own political coming-of-age, offering a noteworthy subtext that dialogues with the situation in Nicaragua today. What was once perceived as an organic revolutionary movement led by a group of intellectuals and activists and coalesced by a party interested primarily in the ouster of Somoza and the welfare of the Nicaraguan people has today devolved into a Frente Sandinista de Liberación Nacional eschewed by many of those who supported it at the height of its ethical authority and national popularity. Unfortunately for many of those who were active in the Frente during the revolution, Cabezas today continues to support Daniel Ortega in the face of continued calls for his resignation and mounting national and international condemnation of the actions of the government forces and the police during the protests April of 2018. Speaking in 2019, for example, Cabezas continued to perceive the public demonstrations as a right-wing conspiracy intended to destabilize the Sandinista revolution (Cabezas, "Interview with 
Fernando Rojas A.”). Upon being asked his opinion of Ortega, declared "Daniel y yo somos la misma cosa, pensamos igual" (Cabezas, "Interview with Fernando Rojas A.”). Notwithstanding violent and repressive actions by the government, his trust in the revolution, in the Frente, and in Ortega continues. As testimonio, Fire From the Mountain evidences the representative experience of one man and how his faith in the Nicaraguan people compelled him to suffer, to struggle, and to liberate his homeland. At this time, "Latin American theological relocation of divine action within the sphere of politics resulted in a secularization of religion, ascribing a religious essence to political action" (Calles Barger 151). While Cabezas may not mention individuals such Gustavo Gutiérrez or Juan Luis Segundo, for example, the presence of a political liberation and the practical and theoretical parallels with liberation theology dovetail with larger concerns regarding the oppressed and the marginalized and open his narrative to further analysis of the commonalities between religious faith and revolutionary action during the Sandinista uprising. As Ignacio Ellacuría wrote, "The promotion of justice through a political option need not be separated from faith, nor even less need it entail a diminishment of faith. Rather, both in principle and in ideal, the more vigorous and incarnated that faith is, the greater will be its contribution to the cause of justice" (28).

\section{Bibliography}

Arias, Arturo. Taking Their Word. Literature and the Signs of Central America. University of Minnesota Press, 2007.

Baez, Silvio José (@silviobaez). “What matters least.”Twitter, 9 July, 2018, 10:41 p.m. https://twitter.com/silviojbaez/status/1016512658307276801 
Barbas-Rhoden, Laura H. "El papel del testimonio en la victoria: Omar Cabezas y el discurso revolucionario en Nicaragua." Confluencia, vol. 14, no. 2 , 1999, pp. 63-75.

Beverley, John. "The Margin at the Center: On Testimonio." The Real Thing.

Testimonial Discourse in Latin America, edited by Georg M.

Gugelberger, Duke University Press, 1996, 23-41.

Bray, David. "Sandinista Socialization.” Caribbean Review, vol. 14, no.3, 1985, pp. 48-49.

Cabezas, Omar. Canción de amor para los hombres. Editorial Nueva Nicaragua, 1988.

. Fire from the Mountain. The Making of a Sandinista. Trans. by

Kathleen Weaver. Plume, 1986.

. Interview. "Con Omar Cabezas." Casa de las Américas, vol. 23, no.138, 1983, pp. 121-25.

. Interview by Fernando Rojas A. "Omar Cabezas, excomandante

sandinista: 'En Nicaragua no hay ninguna crisis." Resumen

Latinoamericano.

http://www.resumenlatinoamericano.org/2019/05/14/omar-cabezas-

excomandante-sandinista-en-nicaragua-no-hay-ninguna-crisis/. Accessed

12 August, 2019.

. La montaña es algo más que una inmensa estepa verde. Editorial Nueva Nicaragua, 1982.

Calles Barger, Lilian. The World Come of Age. An Intellectual History of

Liberation Theology. Oxford UP, 2018.

Conferencia Episcopal de Nicaragua. "Iglesia de Nicaragua repudia acto oprobioso contra nuestros obispos, sacerdotes y laicos." Conferencia Episcopal de Nicaragua. http://www.cennicaragua.org/noticias.php?recordID=525. Accessed 12 August, 2019. 
Dodson, Michael and Laura Nuzzi O'Shaughnessy. Nicaragua's Other Revolution. Religious Faith and Political Struggle. The University of North Carolina Press, 1990.

Elizondo, Virgilio P. “Conditions and Criteria for Authentic Inter-Cultural Theological Dialogue.” Concilium, vol. 171, 1984, pp. 18-24.

Ellacuría, Ignacio. "Liberation Theology and Socio-historical Change in Latin America.” Trans. by James R. Brockman. Towards a Society That Serves its People: The Intellectual Contribution of El Salvador's Murdered Jesuits, edited by John Hassett and Hugh Lacey, Georgetown University Press, 1991, 19-43.

Gauthier, Jeffrey. "Prostitution, Sexual Autonomy, and Sex Discrimination." Hypatia, vol. 26, no.1, 2011, pp. 166-186.

Gugelberger, Georg M. "Decolonizing the Canon: Considerations of Third World Literature." New Literary History, vol. 22, 1991, pp. 505-524.

. "Introduction: Institutionalization of Transgression: Testimonial Discourse and Beyond." The Real Thing. Testimonial Discourse in Latin America, edited by Georg M. Gugelberger, Duke University Press, 1996, $1-22$.

Gutiérrez, Gustavo. A Theology of Liberation. Translated by Sister Caridad Inda and John Eagleston. Orbis, 1988.

Hernández Novas, Raúl. "Romper contra lo ciego.” Casa de las Américas, vol. 23, no.137, 1983, pp. 131-46.

Hood, Edward Waters. "Form and Content in Cabezas Lacayo's Works:

Testimonio literario, literatura testimonial.” PCCLAS Proceedings, vol. 15, nos.1-2, 1991-2, pp. 87-95.

Jones, Robert L. "The Revolutionary Mind: A Theoretical Comparison and Contrast of Testimonial Literature." PCCLAS Proceedings, vol. 15, nos.1-2, 1991-2, pp. 153-62.

Legeay, Stephen. "Review.” Contemporary Sociology, vol. 16, no.3, 1987, pp. $352-4$. 
Mantero, José María. "La mitificación de la revolución sandinista: El caso de Omar Cabezas y La montaña es algo más que una inmensa estepa verde.” Revista de Estudios Hispánicos, vol. 30, no. 2, 2003, pp. 47-57. . Omar Cabezas, Nicaragua, and the Narrative of Liberation: To the Revolution and Beyond. Lexington Books / Rowman \& Littlefield, 2019.

Menton, Seymour. "Review." World Literature Today, vol. 57, no.3, 1983, pp. 437-8.

McCallister, Rick. "La cuestión de género en La montaña es algo más que una inmensa estepa verde." La literatura centroamericana: Visiones y revisiones, edited by Jorge Román-Lagunas, The Edwin Mellen Press, 1994, pp.169-78.

Midence, Carlos. "Presentación.” Maldito país, by José Román, Amerrisque, 2007, pp. 9-12.

https://www.enriquebolanos.org/media/publicacion/Maldito $\% 20 \mathrm{~Pa} \% \mathrm{C} 3$ \%ADs.pdf. Accessed 12 August, 2019.

Orr, Brianne. "From Machista to New Man? Omar Cabezas Negotiates Manhood in the Mountains of Nicaragua." Ciberletras, vol. 22, 2009. http://www.lehman.cuny.edu/ciberletras/v22/orr.html. Accessed 13 August, 2019.

Pailler, Claire. "Review of La montaña es algo más que una inmensa estepa verde." Caravelle, vol. 42, 1984, pp. 209-12.

Picotti, Dina V. "Towards an Intercultural Construction of Rationality." Worldviews and Cultures. Philosophical Reflections from an Intercultural Perspective, edited by Nicole Note, Raúl FornetBetancourt, Josef Estermann and Diederik Aerts, Springer Publishing, 2009, pp. 181-90.

Prada Oropeza, Renato. "De lo testimonial al testimonio. Notas para un deslinde del discurso-testimonio.” Testimonio y literatura, edited by René Jara and Hernán Vidal, Institute for the Study of Ideologies and Literature, 1986, pp. 7-21. 
Puleo, Mev. The Struggle Is One: Voices and Visions of Liberation. State University of New York Press, 1994.

Quin, Alejandro. "Beyond the 'Duality of the World': Guerrilla Experience and Political Ecology (Apropos Omar Cabezas' La montaña es algo más que una inmensa estepa verde)." Romance Notes, vol. 57. no.1, 2017, pp. 3747.

Rodó, José Enrique. Ariel. Translated by F.J. Stimson. Boston, MA: Houghton Mifflin, 1922.

Román, José. Maldito país. Amerrisque, 2007. https://www.enriquebolanos.org/media/publicacion/Maldito\%20Pa\% $\% 3$ \%ADs.pdf. Accessed 12 August, 2019.

Ross, Peter. "Between Fiction and History: Omar Cabezas's La montaña es algo más que una inmensa estepa verde." War and Revolution in Hispanic Literature, edited by Roy Boland and Alun Kenwood, Voz Hispánica, 1990, pp. 97-108.

Rueda Estrada, Verónica. "Testimonios, confesiones y memorias del sandinismo." Cuadernos Americanos, vol. 127, 2009, pp. 145-62.

Sacasa-Ross, Gina. “La Semana Santa en León: tradición, fe y catolicismo.” El Nuevo Diario, 9 April, 2017. https://www.elnuevodiario.com.ni/nacionales/424308-semana-santaleon-tradicion-fe-catolicismo/. Accessed 16 September, 2019.

Sandino, Augusto C. El pensamiento vivo. Tomo I. Editorial Nueva Nicaragua, 1981.

http://www.sergioramirez.com/images/Otros_temas_de_interes/pdf/tomo _1.pdf. Accessed July 2, 2019.

Sawchuck, Dana. "The Catholic Church in the Nicaraguan Revolution: A Gramscian Analysis." Sociology of Religion, vol. 58, no.1, 1997, pp. 3951.

Segundo, Juan Luis. "Críticas y autocríticas de la teología de la liberación." Cambio social y pensamiento cristiano en América latina, edited by José 
Ignacio González Faus and Jon Sobrino, Editorial Trotta, 1993, pp. 215-

36.

Tirado, Manlio. "Narrativa y revolución.” Plural, vol. 12 (2 época), no.133, 1982, pp. 64-5.

Vilanova, Evangelista. "Fe.” Conceptos fundamentales del cristianismo, edited by Casiano Floristán y Juan José Tamayo, Editorial Trotta, 1993, pp. 496509.

Ward, Thomas. Decolonizing Indigeneity. New Approaches to Latin American Literature. Lexington Books, 2017. . La resistencia cultural: la nación en el ensayo de las Américas. Editorial Universitaria, Universidad Ricardo Palma, 2004. 